\title{
$\alpha$-galactosidase and $\beta$-glucosidase Enzyme Activity of Lactic Strains Isolated from Traditional Fermented Foods of West Garo Hills, Meghalaya, India
}

\author{
Birendra Kumar Mishra ${ }^{1}$, Subrota Hati ${ }^{2 *}$, Sujit Das ${ }^{1}$, \\ Santosh Mishra ${ }^{3}$ and Surajit Mandal ${ }^{4}$
}

${ }^{1}$ Department of Rural Development and Agricultural Production, North-Eastern Hill University, Tura campus, Meghalaya-794 001, India

${ }^{2}$ Dairy Microbiology Department, S.M.C. College of Dairy Science, Anand Agricultural University, Anand-388 110, India

${ }^{3}$ Dairy Microbiology Department, GADVASU, Ludhiana, India

${ }^{4}$ Dairy Microbiology Division, National Dairy Research Institute, Karnal-132001, Haryana, India

*Corresponding author

\begin{tabular}{|c|c|}
\hline & A B S T R A C T \\
\hline $\begin{array}{l}\text { Ke y w o r d s } \\
\alpha \text {-galactosidase, } \\
\beta \text {-glucosidase, } \\
\text { Lactobacillus, } \\
\text { fermented food, } \\
\text { Meghalaya. }\end{array}$ & \multirow{3}{*}{$\begin{array}{l}\text { In the study, } \alpha \text {-galactosidase released by Lactic acid bacteria catalyse hydrolysis of } \\
\text { galactose containing oligosaccharide. Similarly, } \beta \text {-glucosidase of lactic acid bacteria } \\
\text { are making a significant contribution to the dietary and sensory attributes of fermented } \\
\text { foods as by deglucosylation, they can release flavour compounds from glucosylated } \\
\text { precursors and could increases the bioavailability of health-promoting secondary } \\
\text { metabolites. Therefore, the aim of this study was to select strains of lactic acid bacteria } \\
\text { isolated from ethnic fermented foods of West Garo Hills of Meghalaya state. Out of } \\
\text { forty nine fermented food-derived isolates, Lactobacillus rhamnosus (K4) was } \\
\text { selected as the maximum producer of } \alpha \text {-galactosidase and Lactobacillus helveticus } \\
\text { (K14) produced maximum } \beta \text {-glucosidase. Hence, these strains can be used as producer } \\
\text { of both, } \alpha \text {-galactosidase and } \beta \text {-glucosidase enzymes during fermentation of complex } \\
\text { sugars. }\end{array}$} \\
\hline Article Info & \\
\hline $\begin{array}{l}\text { Accepted: } \\
\text { 12 March } 2017 \\
\text { Available Online: } \\
10 \text { April } 2017\end{array}$ & \\
\hline
\end{tabular}

\section{Introduction}

Lactic acid bacteria (LAB) of the taxonomic order Lactobacillus (phylum Firmicutes) play an indispensable role in most societies and have been exploited throughout recorded history (Makarova et al., 2006). They are an integral part of traditional food processing and preservation technologies, including the fermentation of dairy products, vegetables and meat. The evolution of LAB is tightly connected to the consumption of fermented foods and many LAB species were 'domesticated' and passed down the generations in the course of emerging food processing technologies.

Lactobacillus sp. possesses glycohydrolases like the enzyme $\alpha$-galactosidase ( $\alpha$-Dgalactoside galactohydrolase, EC 3.2.1.22) hydrolyses terminal, non-reducing $\alpha$-Dgalactose residual in the a-galactosides, as 
well as galactose oligosaccharides such as melibiose, raffinose and stachyose (Dey and Pridham, 1972). $\alpha$ - Galactosidase is not synthesized by humans, and thus the presence of these oligosaccharides could hinder digestion and cause flatulence, since they are utilized by the gas-generating intestinal microorganisms. $\alpha$-Galactosidase can be used to clear these oligosaccharides and upgrade the nutrition of legume food (Thananunkul et $a l .$, 1976). Enzyme treatment with microbial a-galactosidase would be promising for the elimination of these oligosaccharides (Thananunkul et al., 1976). Lactobacillus species have been found in large numbers as part of the intestinal flora of humans and other animals, where they are thought to increase resistance to common intestinal disorders, especially those with a microbial pathogenesis, for example, gastroenteritis (Casas and Dobrogosz, 2000). They can achieve this by fortifying the normal microflora either through their fermentation products or by the production of glycosidases, which degrade carbohydrates, thereby supplying energy for the growth of other bacteria (Sandine et al., 1979).

By definition, $\beta$-D-glucosidases (EC 3.2.1.21) remove glucopyranosyl residues from the non-reducing end of $\beta$-D-glucosides by catalysing hydrolysis of the glycosidicbond. $\beta$-D-Glucosidases occur abundantly in all domains of life and exert diverse biological functions (Cairns and Esen, 2010). LAB involved in plant food fermentations have been investigated extensively with regard to the release of plant metabolites through $\beta$ glucosidase activities. Oleuropein is a phenolic glucoside responsible for the bitterness of unprocessed olives, and partial degradation of oleuropein is required before table olives can be consumed. The most important species for the fermentation of olives is Lactobacillus plantarum. Most of these isolates were able to hydrolyse oleuropein through $\beta$-glucosidase activity (Ghabbour et al., 2011). Soybeans contain high concentrations of their b-glucosides genistin and daidzin. These were reported to be hydrolysed by b-glucosidase activities of LAB during soy milk fermentations (Chin et al., 2006). $\beta$-Glucosidase is considered to be the key enzyme for the bioconversion of isoflavone forms in fermented soy products. It has superior activity for hydrolyzing acetylglycoside and malonylglycoside isoflavones (Park et al., 2006). If $\beta$ glucosidase can effectively convert acetylglycoside and malonylglycoside to their aglycones, it can lead to an enrichment of isoflavone aglycones in soy foods such as soy-based functional fermented food products. Soy isoflavones have been implicated in health benefits, including the potential to reduce the risk of age-related and hormone-related disorders such as cancer, menopausal symptoms, cardiovascular disease and osteoporosis.(Cheng et al., 2013; Okabe et al., 2011; Zhang et al., 2014; Martins et al., 2013; Bedani et al., 2014)

Our present investigation deals with the analysis of $\alpha$-galactosidase and $\beta$-glucosidase enzyme activities of the Lactic acid bacterial cultures obtained from the traditional fermented foods of the West Garo Hills region of Meghalaya with an approach to justify their probiotic potentiality for designing a functional fermented food further.

\section{Materials and Methods}

\section{Sampling and Isolation}

Various samples of fermented foods were obtained from different regions of West Garo Hills in Meghalaya state and $1 \mathrm{ml}$ of a mix of the fermented food samples and poured into $50 \mathrm{ml}$ sterile MRS broth (HiMedia, India) and incubated at $37^{\circ} \mathrm{C}$ for (2-5) days (Abbas and Mahasneh, 2014). The enriched fermented 
food samples were serially diluted in sterile normal saline. Aliquots of $100 \mu \mathrm{l}$ from each dilution were then plated on MRS media supplemented with $0.01 \%$ bromocresol purple as a $\mathrm{pH}$ indicator. Plates were incubated at $37^{\circ} \mathrm{C}$ for $24 \mathrm{~h}$. Presumptive Lactobacillus colonies with yellow halos were randomly picked up from the MRS plates and were further subcultured onto fresh plates of the same medium to ensure purity.

\section{Determination of $\alpha$-galactosidase activity of lactic cultures}

Enzyme extracts from the lactic cultures were assayed for $\alpha$-galactosidase activity according to the method of Hati et al., (2012). The pure lactic cultures were inoculated in $100 \mathrm{ml}$ of sterilized MRS medium and incubated at $37^{\circ} \mathrm{C}$ for $24 \mathrm{~h}$ in an incubator. Then the cultures are centrifuged at 3100-3200rpm for $12 \mathrm{~min}$. Supernatant was discarded and $20 \mathrm{ml}$ of $50 \mathrm{mM}$ sodium citrate buffer ( $\mathrm{pH}-5.5)$ was added to the cell pellet for washing and mixed through vortexing. Then again centrifuge was done at 3100-3200 $\mathrm{rpm}$ for $15 \mathrm{~min}$. The washing step was repeated twice. After that, the cell pellets were suspended in $20 \mathrm{ml}$ of $50 \mathrm{mM}$ sodium citrate buffer $(\mathrm{pH} 5.5)$ and mixed by vortexing. Sonication of the cells upto $15 \mathrm{~min}$ for 3 times at $2^{0} \mathrm{C}$ under optimized conditions at $20 \mathrm{KHz}$ frequency, pulses: 1 minute after 5 minutes intervals and Amplitude: $60 \%$ was carried out. Then, the sonicated mixtures were further centrifuged at $11000 \mathrm{rpm}$ for $30 \mathrm{~min}$ at $4^{0} \mathrm{C}$. $500 \mu \mathrm{l}$ supernatant from sonicated mixtures and 750 $\mu 1 \quad$ of $\quad$-nitrophenyl- $\alpha$-D-galactoside (substrate) was mixed homogenously and incubated at $37^{0} \mathrm{C}$ for $1 \mathrm{~h}$. After that, $500 \mu \mathrm{l}$ of $0.2 \mathrm{M}$ sodium carbonate was added to the mixture to stop the reaction and yellow colour was developed gradually during the addition. Immediately, the absorbance at $410 \mathrm{~nm}$ was measured through double beam UV-VIS spectrophotometer (Systronics, India).

\section{Soybean sample}

Soybeans were obtained from a local market in Anand, Gujarat (India).

\section{Soymilk preparation}

To prepare soymilk, $100 \mathrm{~g}$ of soybeans were soaked for 14-16 h in $1 \mathrm{~L}$ of distilled water at room temperature $\left(28^{\circ} \mathrm{C}\right)$ in a $2 \mathrm{~L}$ beaker as stated by Hati et al., (2014). The soak water was drained from the soybeans, which were then blanched at $98^{\circ} \mathrm{C}$ in boiling distilled water for 15-20 min. The beans were hand washed thoroughly to remove their testa. The soybeans and $500 \mathrm{~mL}$ of boiled distilled water were placed in a blender (Philips, India) and blended for 10-12 min. The boiled water inactivated lipoxygenase enzyme during blending. The resulting slurry was filtered through two layers of muslin cloth. Approximately $500 \mathrm{~mL}$ of soymilk was obtained per $100 \mathrm{~g}$ of soybeans in $500 \mathrm{~mL}$ of water.

\section{Development of Inoculum}

The pure MRS grown lactic cultures obtained from fermented foods were transferred into sterile rehydrated skim milk and glycerol placing $1 \mathrm{~mL}$ aliquots in cryovials and storing at $-20{ }^{\circ} \mathrm{C}$. After two successive transfers of the test organisms in MRS broth (HiMedia, India) and incubation at $37^{\circ} \mathrm{C}$ for $24 \mathrm{~h}$, each activated culture was inoculated into MRS broth and incubated at $37^{\circ} \mathrm{C}$ for $16 \mathrm{~h}$. Theses working cultures were then transferred into soymilk medium to check their activity in this medium. Lactobacillus cultures were selected because of their potential use for making traditional indigenous fermented food product to improve health by providing various health benefits (e.g. antimicrobial, antihypertensive, antioxidative, antidiarrheal, etc.) (Hati et al., 2014). 


\section{Determination of $\beta$-glucosidase activity of} lactic cultures

The $\beta$-glucosidase activity of lactic cultures were determined by estimating the rate of hydrolysis of p-nitrophenol $\beta$-Dglucopyranoside (pNPG) (HiMedia, India) as stated by Scalabrini et al., (1998) and Otieno et al., (2006) with some modifications. Lactic isolates were adapted by two successive transfers in soy milk (Nelson et al., 1976) by incubating at $37^{\circ} \mathrm{C}$ for $24 \mathrm{~h}$. Subsequently, they were added $(1 \% \mathrm{v} / \mathrm{v})$ in $10 \mathrm{ml}$ of soy milk and incubated at $37^{\circ} \mathrm{C}$ for $12 \mathrm{~h}$. For enzymatic activity, $5 \mathrm{mM}$ pNPG (substrate) was prepared in $100 \mathrm{mM}$ sodium phosphate buffer with $\mathrm{pH}$ 7.0. Subsequently, $500 \mu 1$ of this substrate was added to $5 \mathrm{ml}$ of each aliquot sample and incubated at $37^{\circ} \mathrm{C}$ for $30 \mathrm{~min}$. Thereafter, 250 $\mu 1$ of cold $0.2 \mathrm{M}$ sodium carbonate was added to stop the reaction. The mixture thus obtained was centrifuged at $15000 \mathrm{rpm}$ for 30 minutes using a centrifuge (Hermle Z 216 MK, Germany) and filtered through a syringe filters $(0.45 \mu$; Milllipore, USA). The amount of p-nitrophenol released was the indicator of $\beta$-glucosidase activity which was determined by using a spectrophotometer (Systronics UV Vis double beam Spectrophotometer, India) at $410 \mathrm{~nm}$. The enzyme assay is based on the principle that when $\beta$-glucosidase enzyme acts on the substrate pNPG, it releases pnitrophenol in the medium changing its colour to yellow. One unit of the enzyme activity is defined as the quantity of $\beta$-glucosidase action that released one nanomole of $\mathrm{p}$ nitrophenol from pNPG per milliliter per min at $37^{\circ} \mathrm{C}$ under the assay conditions (Hati et al., 2014).

\section{Biochemical characterization}

The isolates were evaluated for carbohydrate fermentation properties, fermentation efficacy of sugars, and enzyme activities were analyzed using API $50 \mathrm{CH}$ kits according to the manufacturer's instructions. Results were scored after incubating at $37^{\circ} \mathrm{C}$ for 24 and 48 h. These results were put on the apiweb ${ }^{\mathrm{TM}}$ identification software with database (V5.1) which used the phenotypic data to predict genus and species of the isolates. Interpretations of the fermentations profiles were facilitated by comparing all results obtained for the tested isolates with information from the computer aided database, apiweb $^{\mathrm{TM}}$ (https://apiweb.biomerieux.com).

\section{Results and Discussion}

A total of forty nine fermented food-derived strains were evaluated for the $\alpha$-galactosidase and $\beta$-glucosidase activity at an absorbance of $410 \mathrm{~nm}$.

\section{Biochemical characterization}

On the basis of both the above enzymatic activities, eight best isolates were selected for their biochemical characterisation. Biochemical tests of all the isolates were carried out by API CH 50 Microbial Identification kit (bioMerieux, India).

\section{$\alpha$-galactosidase activity of the lactic isolates}

The lactic acid bacterial isolates that possessed enzymatic activity showed a yellow colour during the reaction due to the release of p-nitrophenol from $p$-nitrophenyl- $\alpha$-Dgalactoside (substrate).The highest enzyme activity was exhibited by Lactobacillus rhamnosus (K4) as 0.407 enzyme units followed by Lactobacillus fermentum (K3) with 0.399 enzyme units and then Lactobacillus fermentum (K16) with 0.357 enzyme units. Hence in majority, these specific three isolates were found to be predominant over the rest (Figure 1). Hati et $a l .$, (2012) previously reported that $\alpha$ galactosidase activity depends on the strain 
and amount of oligosaccharides present in growth medium. L. rhamnosus C6 strain was selected for the development of soy dahi (curd) as it produced maximum amount of $\alpha$ galactosidase enzyme which in concordance to our study relating to L. rhamnosus $\mathrm{K} 4$ strain being adequate producer of $\alpha$ galactosidase.
As reported by Milica et al., (2016) in terms of $\alpha$ - galactosidase activity, enzyme extracted from $L$. reuteri was the most active one (1.27 $\mathrm{IU} / \mathrm{mL}$ ), while notably less active $\alpha$ galactosidases were extracted from $L$. acidophilus $(0.255 \quad \mathrm{IU} / \mathrm{ml})$ and $S$. thermophilus $(0.181 \mathrm{IU} / \mathrm{ml})$.

Fig.1 Alpha galactosidase activity of forty nine lactic isolates from the fermented foods of West Garo Hills, Meghalaya

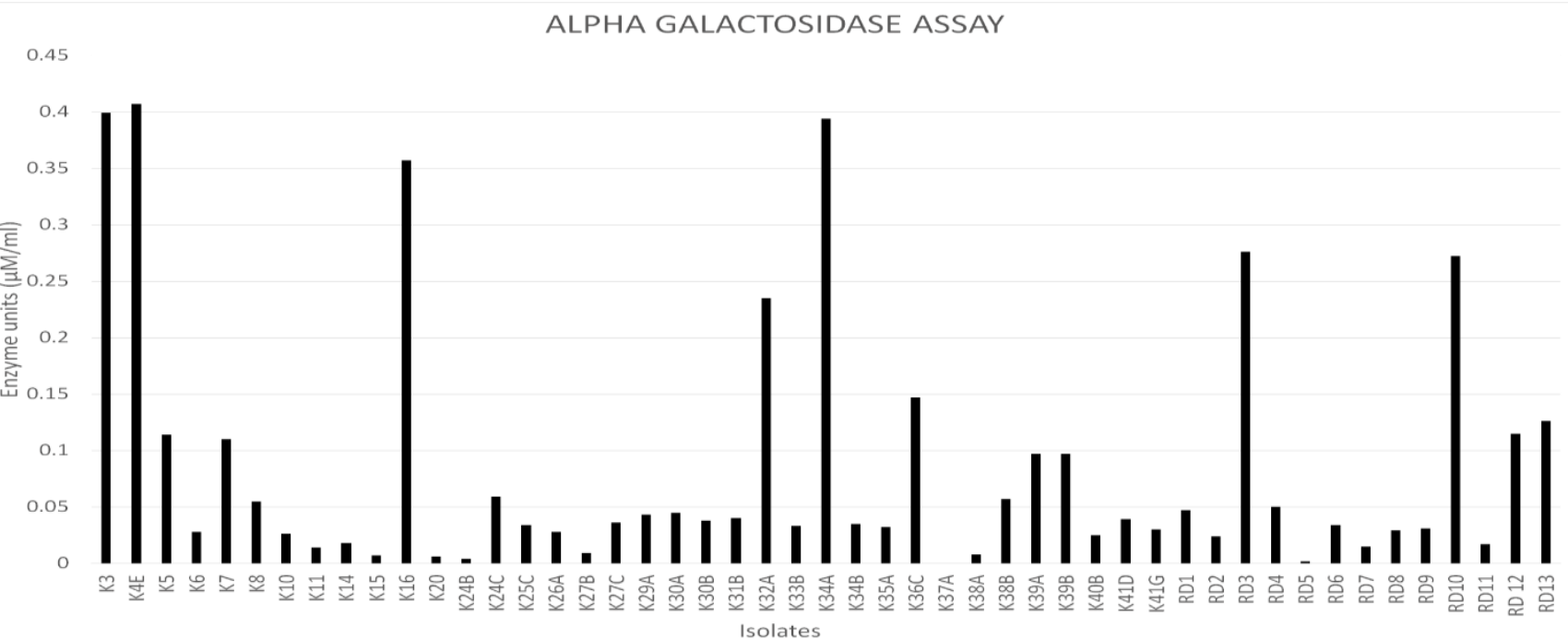

Fig.2 Beta glucosidase activity of forty nine lactic isolates from the fermented foods of West Garo Hills, Meghalaya

BETA GLUCOSIDASE ASSAY

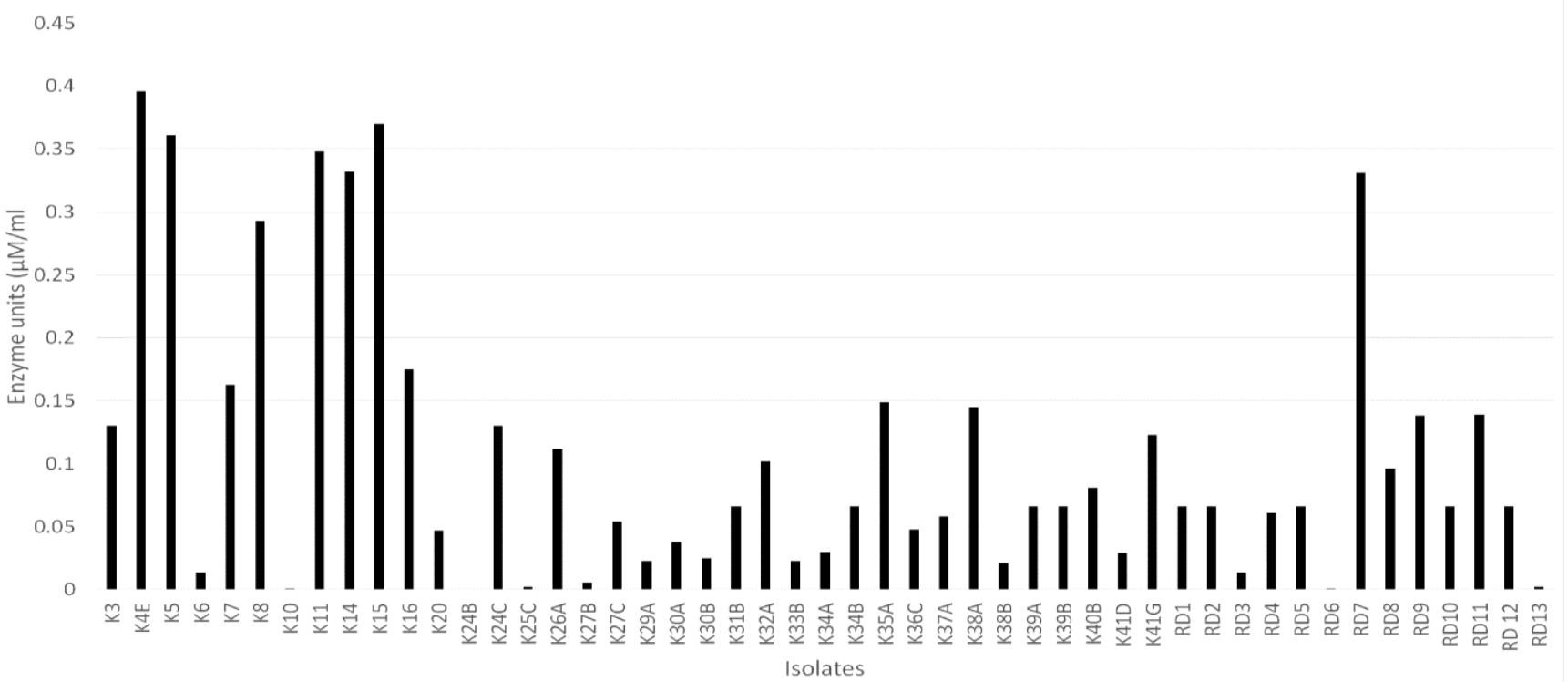


Table.1 Biochemical tests of LAB isolates through API 50CH kit

\begin{tabular}{|c|c|c|c|c|c|c|c|c|c|}
\hline & API $50 \mathrm{CH}$ & K3A & K4E & K5 & RD7 & K7 & K14 & K16 & K32A \\
\hline 0 & Control & - & - & - & - & - & - & - & - \\
\hline 1 & Glycerol & - & - & - & - & - & - & - & - \\
\hline 2 & Erythritol & - & - & - & - & - & - & - & - \\
\hline 3 & D-Arabinose & - & - & - & - & - & - & - & - \\
\hline 4 & L-Arabinose & - & - & - & + & + & - & + & + \\
\hline 5 & D-Ribose & + & + & + & + & + & - & + & + \\
\hline 6 & D-Xylose & - & - & - & - & - & - & - & + \\
\hline 7 & L-Xylose & - & - & - & - & - & - & - & - \\
\hline 8 & D-Adonitol & - & - & - & - & - & - & - & - \\
\hline 9 & Methyl $\beta$-D-Xylopyranoside & - & - & - & + & - & - & - & - \\
\hline 10 & D-Galactose & + & + & + & + & + & - & + & - \\
\hline 11 & D-Glucose & + & + & + & + & + & + & + & - \\
\hline 12 & D-Fructose & + & + & + & + & + & - & + & + \\
\hline 13 & D-Mannose & + & + & + & - & + & - & + & - \\
\hline 14 & L-Sorbose & - & + & - & - & + & - & - & - \\
\hline 15 & L-Rhomnose & - & - & - & - & + & - & - & - \\
\hline 16 & Dulcitol & - & + & - & - & - & - & - & - \\
\hline 17 & Inositol & - & - & - & + & - & - & - & - \\
\hline 18 & D-Mannitol & - & + & - & - & + & - & + & - \\
\hline 19 & D-Sorbitol & - & + & - & + & + & - & - & - \\
\hline 20 & $\begin{array}{l}\text { Methyl } \quad \alpha-D- \\
\text { Mannopyranoside }\end{array}$ & - & - & - & - & + & - & - & - \\
\hline 21 & Methyl $\alpha$-D-Glucopyranoside & - & - & - & + & - & - & - & - \\
\hline 22 & N-Acetyl Glucosamine & - & + & - & + & + & + & + & - \\
\hline 23 & Amygdalin & - & - & - & + & + & - & - & - \\
\hline 24 & Arbutin & - & + & - & + & + & - & + & - \\
\hline 25 & Esculin Ferric citrate & + & + & + & + & + & - & + & + \\
\hline 26 & Salicin & - & + & - & + & + & - & + & - \\
\hline 27 & D-Celiobiose & - & + & - & + & + & - & + & - \\
\hline 28 & D-Maltose & + & + & + & + & + & - & + & - \\
\hline 29 & $\begin{array}{l}\text { D-Lactose } \\
\text { (bovine origin) }\end{array}$ & + & + & + & + & + & + & + & - \\
\hline 30 & D-Melibiose & + & + & + & + & + & - & + & - \\
\hline 31 & $\begin{array}{l}\text { D-Saccharose } \\
\text { (Sucrose) }\end{array}$ & + & + & + & + & + & - & + & - \\
\hline 32 & D-Trehalose & + & + & + & - & + & - & + & + \\
\hline 33 & Inulin & - & - & - & + & - & - & - & - \\
\hline 34 & D-Melezitose & - & + & - & - & + & - & - & - \\
\hline 35 & D-reffinose & + & + & + & - & + & + & + & - \\
\hline 36 & Amidon(starch) & - & - & - & - & - & - & - & - \\
\hline 37 & Glycogen & - & - & - & - & - & - & - & - \\
\hline 38 & Xylitol & - & - & - & + & - & - & - & - \\
\hline 39 & Gentiobiose & - & + & - & + & + & - & + & - \\
\hline 40 & D-Turanose & - & - & - & - & + & - & - & - \\
\hline
\end{tabular}




\begin{tabular}{|c|c|c|c|c|c|c|c|c|c|}
\hline 41 & D-Lyxose & - & - & - & - & - & - & - & - \\
\hline 42 & D-Tagatose & - & + & - & - & + & - & + & - \\
\hline 43 & D-Fucose & - & - & - & - & - & - & - & - \\
\hline 44 & L-Fucose & - & - & - & + & - & - & - & - \\
\hline 45 & D-Arbitol & - & - & - & - & - & - & - & - \\
\hline 46 & L-Arbitol & - & + & - & + & - & - & - & - \\
\hline 47 & Potassium Gluconate & + & + & + & - & + & - & + & - \\
\hline 48 & Potassium2-KetoGluconate & - & - & - & - & - & - & - & - \\
\hline 49 & Potassium 5-keto Gluconate & - & - & - & & - & - & - & - \\
\hline 50 & Catalase Test & - & - & - & - & - & - & - & - \\
\hline
\end{tabular}

\section{$\beta$-glucosidase activity of lactic isolates}

The rate of hydrolysis of the substrate, $\mathrm{p}$ nitrophenol $\beta$-D-glucopyranoside (pNPG) by the lactic isolates determined the $\beta$ glucosidase activity of them (Figure 2). The highest enzyme activity was exhibited by Lactobacillus rhamnosus (K4) as 0.396 enzyme units followed by Lactobacillus fermentum (K5) with 0.361 enzyme units and Lactobacillus helveticus (K14) with 0.332 enzyme units. Hence, these specific three isolates proved to be the maximum producer of $\beta$-glucosidase enzyme as compared to the rest of the other isolates.

Previously, Hati et al., (2014) reported $\beta$ Glucosidase activity of six Lactobacillus cultures that exhibited different levels of $\beta$ Glucosidase activity during their growth under optimal conditions and Lactobacillus rhamnosus C6 showed the highest activity $(1.66 \mathrm{U} \mathrm{mL}-1)$ among the others. Matsuda $e t$ al., (1994) reported L. rhamnosus can be used to increase isoflavone concentrations in fermented soy foods as it possesses $\beta$ Glucosidase activity. Our study is in agreement with Jose et al., (2009) who also reported that $L$. rhamnosus strains are generally active, showing higher $\beta$ Glucosidase specific activity compared with that of other Lactobacillus strains.
In conclusion, in this study, it was clearly shown that some strains of lactic acid bacteria obtained from the traditional fermented foods of West Garo Hills are simultaneous producers of both, $\alpha$-galactosidase and $\beta$ glucosidase but among them Lactobacillus rhamnosus (K4) was the most potent producer of $\alpha$-galactosidase and $\beta$-glucosidase followed by Lactobacillus fermentum (K3) and Lactobacillus helveticus(K14). These cultures could be used for the production of fermented soy based foods.

\section{Acknowledgement}

The authors are grateful to the Department of Biotechnology (DBT), Ministry of Science and Technology, New Delhi, India for the financial assistance under Twining Project 2013 in collaboration with Anand Agricultural University, Anand, Gujarat and North-Eastern Hill University, Tura Campus, Meghalaya.

\section{References}

Abbas, M.M., and Mahasneh, A.M. 2014. Isolation of Lactobacillus strains with probiotic potential from camel's milk. Afr. J. Microbiol. Res., 8(15): 16451655.

Bedani, R., Vieira, A.D.S., Rossi, E.A., and Saad, S.M.I. 2014. Tropical fruit pulps decreased probiotic survival to in 
vitrogastrointestinal stress in synbiotic soy yoghurt with okara during storage. LWT - Food Sci. Technol., 55: 436443.

Cairns, J.R.K., and Esen, A. 2010. $\beta$ Glucosidases. Cell Mol. Life Sci., 67: 3389-3405.

Casas, I.A., and Dobrogosz, W.J. 2000. Validation of the probiotic concept: Lactobacillus confers broad-spectrum protection against disease in humans and animals. Microbial Ecol. Health Dis., 12: 247-285.

Cheng, C.P., Tsai, S.W., Chiu, C.P., Pan, T.M., and Tsai, T.Y. 2013. The effect of probiotic-fermented soy milk on enhancing the NO-mediated vascular relaxation factors. J. Sci. Food Agric., 93: 1219-1225.

Chien, H.L., Huang, H.Y., and Chou, C.C. 2006. Transformation of isoflavone phytoestrogens during the fermentation of soymilk with lactic acid bacteria and bifidobacteria. Food Microbiol., 23: 772-778.

Dey, P.M., Pridham, J.B. 1972. Biochemistry of $\alpha$ - galactosidase. Adv. Enzymol., 36: 91-130.

Ghabbour, N., Lamzira, Z., Thonart, P., Cidalia, P., Markaoui, M., and Asehraou, A. 2011. Selection of oleuropein-degrading lactic acid bacteria strains isolated from fermenting Moroccan green olives. Grasas Aceites, 62: 84-89.

Hati, S., Vij, S., Mandal, S., Malik, R.K., Kumari, V., and Khetra, Y. 2013. $\alpha$ galactosidase activity and oligosaccharides Utilization by Lactobacilli during fermentation of Soy milk. J. Food Processing and Preservation, 38: 1065-107.

Hati, S., Vij, S., Singh, B.P., Mandal, S. 2014. $\beta$-Glucosidase activity and bioconversion of isoflavones during fermentation of soymilk. J. Sci. Food
Agric., 95: 216-220.

Jose, A., Bouaid, A. and Martinez, M. 2009. Production of biodiesel from bioethanol and Brassica carinata oil: oxidation stability study. Biores. Technol., 100: 2234-2239.

Makarova, K., Slesarev, A., and Wolf, Y. 2006. Comparative genomics of the lactic acid bacteria. P Natl. Acad. Sci. USA, 103: 15611-15616.

Martins, E.M.F., Ramos, A.M., Vanzela, E.S.L., Stringheta, P.C., Pinto, C.L.O., and Martins, J.M. 2013. Products of vegetable origin: a new alternative for the consumption of probiotic bacteria. Food Res. Int., 51:764-770.

Matsuda, S., Norimoto, F., Matsumoto, Y., Ohba, R., Teramoto, Y., and Ohta, N. 1994. Solubilization of a novel isoflavone glycoside-hydrolyzing $\beta$ glucosidase from Lactobacillus casei subsp. rhamnosus. J. Ferment. Bioeng., 77: 439-441.

Milica, C., Katarina, B., Marija, C., Sonja, J., Ana, M., Maja, V.S., and Dejan, B. 2016. Selection of lactic acid bacteria strain for simultaneous production of $\alpha$ and $\quad \beta$-galactosidases. Zastita Materijala, 57(2): $265-273$.

Otieno, D.O., and Shah, N.P. 2007. Endogenous $\beta$-glucosidase and $\beta$ galactosidase activities from selected probiotic micro-organisms and their role in isoflavone biotransformation in soymilk. J. Appl. Microbiol., 103: 910917.

Okabe, Y., Shimazu, T., and Tanimoto, H. 2011. Higher bioavailability of isoflavones after a single ingestion of aglycone-rich fermented soybeans compared with glucoside-rich nonfermented soybeans in Japanese postmenopausal women. J. Sci. Food Agric., 91: 658-663.

Park, Y.K., Aguiar, C.L., Alencar, S.M., Mascrenhas, H.A.A., and Scamparini, 
A.R.P. 2002. Conversion of malonyl $\alpha$ glucoside isoflavones into glycoside isoflavones found in some cultivars of Brazilian soybeans. Cienc. Technol. Alim., 22: 130-135.

Sandine, W.E. 1979. Roles of Lactobacillus in the intestinal tract. J. Food Protect., 42: 259-262.

Scalabrini, P., Rossi, M., Spettoli, P. and Matteuzzi, D. 1998. Charaterization of Bifidobacterium strains for use in soymilk fermentation. Int. J. Food
Microbiol., 39: 213-219.

Thananunkul, D., Tanaka, M., Chichester, C.O., Li, T. 1976. Degradation of raffinose and stachyose in soybean milk by a-galactosidase from Mortierellavinacea. gel. J. Food Sci., 41: 173-175.

Zhang, S.T., Shi, Y., Zhang, S.L., Shang, W., Gao, X.Q., and Wang, H.K. 2014. Whole soybean as probiotic lactic acid bacteria carrier food in solid-state fermentation. Food Control, 41: 1-6.

\section{How to cite this article:}

Birendra Kumar Mishra, Subrota Hati, Sujit Das, Santosh Mishra and Surajit Mandal. 2017. $\alpha$ galactosidase and $\beta$-glucosidase Enzyme Activity of Lactic Strains Isolated from Traditional Fermented Foods of West Garo Hills, Meghalaya. Int.J.Curr.Microbiol.App.Sci. 6(4): 11931201. doi: https://doi.org/10.20546/ijcmas.2017.604.146 